\title{
Kemampuan Berpikir Kritis Siswa pada Materi Barisan dan Deret Berdasarkan Gaya Berpikir
}

\section{Aulia Firdaus ${ }^{1}$, Lulu Choirun Nisa ${ }^{2}$, Nadhifah $^{3}$}

1,2Universitas Islam Negeri, Walisongo Semarang, Indonesia

Corresponding Author: auliafirdaus350@gmail.com

DOI: http://dx.doi.org/10.15294/kreano.v10i1.17822

Received : January 2019; Accepted: June 2019; Published: June 2019

\begin{abstract}
Abstrak
Tujuan dari penelitian ini adalah untuk mendeskripsikan kemampuan berpikir kritis siswa dalam menyelesaikan soal matematika pada pokok bahasan barisan dan deret berdasarkan gaya berpikirnya. Jenis penelitian ini adalah deskriptif kualitatif dengan subjek penelitian siswa kelas XI MIPA 1 yang berjumlah 34 siswa. Dengan tes gaya berpikir Gregorc, dari ke-34 siswa tersebut diperoleh lima siswa memiliki gaya berpikir sekuensial konkret, delapan siswa bergaya sekuensial abstrak, lima siswa bergaya acak konkret, dan 16 siswa memiliki gaya berpikir acak abstrak. Dari masing-masing kelompok gaya berpikir tersebut diambil dua siswa untuk dianalisis lebih lanjut kemampuan berpikir kritisnya. Pengumpulan data dilakukan dengan tes dan wawancara. Hasil penelitian menunjukkan bahwa kemampuan berpikir kritis siswa dari kelompok gaya berpikir konkret lebih baik daripada siswa dari kelompok abstrak, dan siswa dengan jenis gaya berpikir sekuensial abstrak dan acak abstrak memiliki kemampuan berpikir kritis lebih rendah dibandingkan dengan gaya berpikir lainnya. Secara bertutut-turut, kemampuan berpikir kritis terbaik dimiliki oleh siswa dengan gaya berpikir sekuensial konkret yang memenuhi 4 kemampuan, acak konkret yang memenuhi 3 kemampuan, serta sekuensial abstrak dan acak abstrak yang hanya memenuhi 1 kemampuan berpikir kritis.
\end{abstract}

\begin{abstract}
The purpose of this study is to describe students' critical thinking skills in solving mathematical problems on the subject line and series based on their thinking style. This type of research is descriptive qualitative with the research subjects of class XI MIPA I numbering 34 students. With the Gregorc thinking style test, five of the students obtained five students had concrete sequential thinking styles, eight students in abstract sequential style, five students in concrete random style, and 16 students had abstract random thinking styles. From each group of thinking styles, two students were taken to further analyze their critical thinking skills. Data collection is done by tests and interviews. The results showed that students' critical thinking skills from concrete thinking groups were better than students from abstract groups, and students with abstract and random abstract sequential thinking types had lower critical thinking skills than other thinking styles. Taken together, the best critical thinking skills are possessed by students with concrete sequential thinking styles that fulfill 4 abilities, concrete random that meet 3 abilities, as well as abstract and random sequential abstracts that only fulfill I critical thinking ability.
\end{abstract}

Keywords: effectiveness; TPS; mouse mischief

\section{PENDAHULUAN}

Matematika merupakan salah satu bidang studi yang memiliki peranan penting dalam dunia pendidikan. Hal itu dapat dilihat dalam kurikulum pendidikan yang ada di Indone- sia menempatkan matematika sebagai mata pelajaran wajib yang perlu diberikan kepada siswa mulai dari sekolah dasar hingga sekolah menengah. Hal tersebut dilatarbelakangi karena mata pelajaran matematika dapat 
membekali siswa di Indonesia untuk memiliki kemampuan memecahkan masalah, berpikir kritis, logis dan kreatif dalam menghadapi segala jenis tantangan di era globalisasi seperti sekarang ini. Hal itu sebagaimana yang tertuang dalam Permendikbud nomor 58 tentang Pedoman Mata Pelajaran Matematika dan Permendikbud nomor 21 tentang Standar Isi yang menyebutkan bahwa manfaat yang diperoleh dari pelajaran matematika diantaranya adalah (1) mampu menggunakan kemampuan berpikir dan bernalar dalam pemecahan masalah, (2) mampu mengkomunikasikan gagasan secara efektif, (3) memiliki sikap dan perilaku yang sesuai dengan nilainilai matematika, seperti taat azas, konsisten, menjunjung tinggi kesepakatan, menghargai perbedaan pendapat, teliti tanggung, kreatif, dan terbuka. Tampak bahwa tujuan dari pembelajran matematika yaitu membekali siswa memiliki kemampuan memecahkan masalah, bernalar, berpikir logis, analistis, sistematis, kreatif, dan bersikap kritis dengan mengkomunikasikan gagasan berdasarkan informasi yang diperoleh sehingga mampu bertahan hidup pada keadaan yang selalu berubah, tidak pasti dan kompetitif.

Berpikir kritis merupakan komponen penting yang harus dimiliki oleh setiap siswa, karena seiring dengan perkembangan teknologi dan ekonomi yang begitu pesat, setiap waktu seseorang dituntut untuk berpikir kritis, tidak hanya menerima sesuatu informasi begitu saja, namun harus bisa memilah-milih informasi yang diterimanya serta mencari sebab akibat dan buktinya secara logis dan rasional. Oleh karena itu, menanamkan kebiasaan berpikir kritis matematis perlu dilakukan agar siswa dapat mengatasi berbagai persoalan dan permasalahan yang terjadi dalam kehidupan sehari-hari (Somakim, 2011).

Dengan kemampuan berpikir kritis yang baik, siswa tidak akan dengan mudah menerima sesuatu yang diterimanya begitu saja, tetapi siswa juga dapat mempertanggung-jawabkan pendapatnya disertai dengan alasan yang logis (Hendriana et al, 2017). Kemampuan berpikir kritis juga dapat membiasakan siswa untuk bisa bersikap rasional dalam menentukan dan memilih alternatif pilihan yang terbaik untuk dirinya. Karena penting untuk menanamkan kemampuan berpikir kritis, maka berpikir kritis perlu diberikan kepada anak-anak sejak usia dini.

Masalah yang timbul dalam lapangan ialah kegiatan belajar mengajar yang dilakukan guru masih berpusat pada guru yang mengakibatkan kemampuan berpikir siswa belum sepenuhnya dikembangkan. Seperti halnya hasil pengamatan lapangan di MA NU o3 Sunan Katong bahwa kegiatan pembelajaran masih bersifat teacher center. Hal itu ditandai dengan guru menyajikan materi, dan memberikan contoh-contoh kepada siswa pada praktek pembelajarannya. Siswa cenderung selalu dibimbing atau diberikan petunjuk penyelesaian masalah secara lengkap, sehingga siswa belum mampu untuk belajar memecahkan masalah secara mandiri menggunakan kemampuan yang dimilikinya untuk menyelesaikan masalah.

Hal di atas mengakibatkan kemampuan berpikir kritis siswa belum berkembang optimal. Secara nasional, berdasarkan hasil penelitian yang dilakukan PISA pada tahun 2015 untuk bidang studi matematika, Indonesia mendapat skor 386 sementara rata-rata skor negara OECD 490 dan Indonesia menempati rangking 63 untuk bidang matematika dari 69 negara (Iswadi, 2016). Hal ini menunjukkan bahwa siswa Indonesia masih lemah dalam menyelesaikan soal-soal yang difokuskan pada mathematics literacy yang ditunjukkan oleh kemampuan siswa dalam menggunakan matematika yang mereka pelajari untuk menyelesaikan persoalan dalam kehidupan sehari-hari. Sementara hasil TIMSS menunjukkan bahwa rata-rata siswa Indonesia lemah dalam menyelesaikan soal-soal yang berkaitan dengan pembuktian dan pemecahan masalah yang memerlukan penalaran matematika (Marwan dan Ikhsan, 2016). Melihat hasil skor Indonesia baik pada survey PISA maupun TIMSS maka harus ada upaya untuk mengidentifikasi penyebabnya dan upaya untuk memperbaikinya.

Melihat permasalahan-permasalahan tersebut, jelas bahwa kemampuan berpikir kritis harus dikembangkan oleh guru, karena itu guru hendaknya mengidentifikasi siswa dan memperbaiki praktik mengajarnya yang 
lebih baik. Namun, sebelum menggunakan metode pembelajaran yang tepat maka perlu adanya analisis kemampuan berpikir kritis terlebih dahulu agar solusi yang diberikan tepat, efektif, dan efisien. Sebagaimana Rahmawati, et al (2016) menyampaikan bahwa keterampilan siswa dalam berpikir kritis perlu dinilai/ diukur terlebih dahulu sebelum memilih metode pembelajaran yang tepat dengan tujuan dapat mendiagnosis seberapa tinggi tingkat keterampilan berpikir kritis sehingga dapat memberikan umpan balik terhadap siswa tentang kemampuan berpikir kritis yang mereka miliki.

Selain itu, untuk mengembangkan kemampuan berpikir kritis siswanya, guru harus memperhatikan karakteristik siswa karena hakikatnya masing-masing siswa memiliki kelebihan-kelebihan begitu juga keterbatasanketerbatasan dengan kemampuan yang dimiliknya. Dengan demikian, dalam memahami dan menyerap pelajaran yang disampaikan guru setiap siswa juga berbeda. Oleh karena itu, guru hendaknya memahami bahwa perbedaan dalam kemampuan tersebut memerlukan perlakuan-perlakuan yang bersifat kolektif (Mulyono, 2012). Salah satu hal yang perlu diperhatikan adalah gaya berpikir setiap siswa.

Gaya berpikir merupakan cara yang lebih disukai seseorang dalam mengolah dan mengatur informasi yang diperoleh dari orang lain. Sebagaimana DePorter dan Hernacki (2015) menyimpulkan bahwa gaya berpikir merupakan perpaduan antara bagaimana seseorang menerima dan mengolah informasi yang diperolehnya di dalam otak. Oleh karena itu, gaya berpikir seseorang akan berbeda-beda sesuai dengan kebiasaan dalam mengolah dan mengatur informasi yang diperolehnya.

Kemampuan berpikir dan memproses informasi setiap orang berbeda-beda akan mempengaruhi kemampuan berpikir kritis yang dimiliki setiap orang. Gregorc (1982) menyimpulkan bahwa kemungkinan otak manusia dalam hal mengelola informasi ada dua, yaitu: persepi konkret dan abstrak, kemudian otak dalam hal mengatur informasi yang diterima terbagi dua secara sekuensial dan acak yang selanjutnya menggabungkan empat kombinasi perilaku yang disebut dengan gaya berpikir meliputi: gaya berpikir sekuensial konkret (SK), gaya berpikir sekuensial abstrak (SA), gaya berpikir acak konkret (AK), dan gaya berpikir acak abstrak (AA) (DePorter dan Hernacki, 2015). Oleh sebab itu, perbedaan antara gaya berpikir tersebut dipandang dari segi kebergantungan siswa kepada penerimaan dan pengolahan informasi dari guru akan menghasilkan kemampuan berpikir kritis yang berbeda pula terutama di dalam pembelajaran matematika.

Tujuan dari penelitian ini adalah: (1) untuk mengetahui jenis gaya berpikir siswa MA NU o3 Sunan Katong, (2) untuk mendeskripsikan kemampuan berpikir kritis siswa kelas XI ditinjau dari gaya berpikir siswa.

Ennis (2011) mendefinisikan berpikir kritis merupakan proses berpikir yang masuk akal dan reflektif yang beralasan dan difokuskan pada penetapan apa yang dipercayai atau yang dilakukan. Sementara itu, Duron (2006) bahwa berpikir kritis dapat diartikan sebagai kemampuan untuk menganalisis dan mengevaluasi informasi. Sedangkan, Paul dan Elder (2006) mendefinisikan berpikir kritis sebagai seni berpikir untuk menganalisis dan mengevaluasi terlebih dahulu sesuai dengan pandangannya. Lain halnya dengan Hendriana et al (2017) mendefinisikan berpikir kritis sebagai proses yang sistematis sehingga memungkinkan seseorang untuk merumuskan dan mengevaluasi keyakinan dan pendapatnya sendiri. Dari pendapat yang telah dipaparkan di atas dapat ditarik simpulan bahwa berpikir kritis adalah sebuah kegiatan berpikir secara sistematis untuk menganalisis dan mengevaluasi suatu permasalahan yang dihadapi sesuai dengan keyakinan dan pendapat mereka sendiri.

Ennis (2011) menyebutkan bahwa seseorang yang memilki kemampuan berpikir kritis harus memenuhi 12 indikator kemampuan berpikir kritis yang dirangkum dalam 5 kemampuan, sehingga dalam penelitian ini, peneliti menggunakan kemampuan berpikir Ennis untuk mengetahui sejauh mana kemampuan berpikir kritis siswa. yaitu: (1) melakukan klarifikasi dasar meliputi: memfokuskan pertanyaan, menganalisis argumen, dan menanyakan dan menjawab pertanyaan yang membutuhkan penjelasan atau tantangan, 
(2) memberikan dasar untuk suatu keputusan meliputi: menilai kredibilitas sumber informasi, dan melakukan observasi dan menilai laporan hasil observasi, (3) menyimpulkan meliputi: membuat deduksi dan menilai hasil deduksi, membuat kesimpulan, membuat penilaian, (4) melakukan klarifikasi lebih lanjut meliputi: mendefinisikan dan menilai definisi, dan mengidentifikasi asumsi, (5) melakukan dugaan dan keterpaduan meliputi: menduga dan memadukan.

Sementara itu, dalam penelitian ini, gaya berpikir yang digunakan menurut Gregorc. Gregorc (dalam DePorter dan Hernacki, 2015) membagi 4 kombinasi kelompok gaya berpikir sebagai berikut: sekuensial konkret (SK), sekuensial abstrak (SA), acak konkret $(A K)$, dan acak abstrak (AA), orang yang termasuk dalam kriteria sekuensial cenderung memiliki dominasi otak kiri, proses berpikir otak kiri bersifat logis, sekuensial, linear, dan rasional, sedang orang-orang berpikir secara acak biasanya menggunakan otak kanan cara berpikir otak kanan bersifat acak, tidak teratur, intuitif, dan holistik.

DePorter dan Hernacki (2015) mendefinisikan karakterisik gaya berpikir sebagai berikut: Pemikir sekuensial konkret (SK) lebih suka mengerjakan segala sesuatu dengan teratur sesuai perintah atau arahan. Pemikir acak konkret (AK) lebih suka memecahkan masalah dan mengerjakan segala sesuatu sesuai dengan cara mereka sendiri. Pemikir acak abstrak (AA) sangat dipengaruhi oleh emosi maupun perasaan. Pemikir AA lebih suka belajar jika diberi pedoman yang luas dan dipersonifikasikan secara keseluruhan. Sedangkan pemikir sekuensial abstrak (SA) lebih suka menganalisis informasi secara urut sebelum bertindak untuk mengambil sebuah keputusan.

\section{METODE}

Penelitian ini merupakan jenis penelitian kualitatif karena tujuan yang diharapkan untuk mendeskripsikan kemampuan berpikir kritis siswa yang mengacu pada kemampuan berpikir kritis Ennis (2011) berdasarkan gaya berpikir siswa dalam menyelesaikan soal matematika pada pokok bahasan barisan dan deret di kelas XI MIPA 1 MA NU o3 Sunan Katong ta- hun ajaran 2017/2018.

Jumlah seluruh siswa pada kelas ini sebanyak 34 siswa, sedangkan subjek penelitian berjumlah delapan siswa yang terdiri dari masing-masing dua siswa pada setiap gaya berpikir. Sementara itu, cara pengambilan subjek penelitian dilakukan teknik purposive sampling dimana peneliti meminta pertimbangan kepada guru mata pelajaran matematika di MA NU o3 Sunan Katong untuk menentukan kelas yang dijadikan subjek penelitian. Pemilihan subjek penelitian ini ditentukan berdasarkan tes gaya berpikir siswa yang dikembangkan oleh John Parks Le Tellier dalam bukunya DePorter and Hernacki (2015) sehingga tidak perlu dilakukan validasi instrumen tes.

Gaya berpikir yang digunakan dalam penelitian ini mengacu pada gaya berpikir menurut Gregorc yang meliputi gaya berpikir sekuensial konkret (SK), sekuensial abstrak (SA), acak konkret (AK), dan acak abstrak (AA). Instrumen yang digunakan untuk membantu mengenal gaya berpikir siswa di adaptasi dari rancangan instrumen John Park Le Tellier dalam bukunya DePorter dan Hernacki (2015). Sementara itu, instrumen kemampuan berpikir kritis yang digunakan pada penelitian ini menggunakan soal essay pada pokok bahasan barisan dan deret dengan jumlah soal sebanyak delapan butir. Adapun kemampuan berpikir kritis yang diukur pada penelitian ini menagcu pada kemampuan berpikir Ennis (2011).

\section{HASIL DAN PEMBAHASAN}

Hasil tes gaya berpikir siswa kelas XI MIPA 1 MA NU o3 Sunan Katong seperti ditunjukkan pada tabel di bawah ini.

Tabel 1. Hasil Tes Gaya Berpikir Kelas XI MIPA 1

\begin{tabular}{ccc}
\hline Jenis Gaya Berpikir & $\begin{array}{c}\text { Jumlah } \\
\text { Siswa }\end{array}$ & Persentase (\%) \\
\hline Sekuensial Konkrit & 5 & 14,7 \\
Sekuensial Abstrak & 8 & 23,5 \\
Acak Konkrit & 5 & 14,7 \\
Acak Abstrak & 16 & 47,1 \\
\hline Jumlah & 34 & 100 \\
\hline
\end{tabular}

Berdasarkan Tabel 1, jumlah siswa dengan gaya berpikir sekuensial berjumlah lima siswa $(14,7 \%)$, delapan siswa $(23,5 \%)$ dengan 
gaya berpikir sekuensial abstrak, lima siswa $(14,7 \%)$ dengan gaya berpikir acak konkret, dan 16 siswa $(47,1 \%)$ dengan gaya berpikir acak abstrak.

Sementara itu, hasil analisis kemampuan berpikir kritis siswa berdasarkan gaya berpikir, di peroleh hasil sebagai berikut:

\section{Kemampuan Berpikir Kritis Siswa den- gan Gaya Berpikir Sekuensial Konkret (SK)}

Berdasarkan hasil analisis, dapat disimpulkan bahwa siswa dengan gaya berpikir SK mampu memenuhi keempat kemampuan berpikir kritis menurut Ennis (2011) yaitu kemampuan melakukan klarifikasi dasar, kemampuan memberikan dasar untuk suatu keputusan, kemampuan menyimpulkan dan kemampuan melakukan klarifikasi lebih lanjut dengan baik.

Berdasarkan hasil analisis data kemampuan melakukan klarifikasi dasar, siswa dengan gaya berpikir SK cenderung mengamati segala sesuatu menggunakan indera penglihatannya dalam mengidentifikasi masalah yang ada pada soal sebelum bertindak dengan baik. Hal ini sesuai dengan DePorter dan Hernacki (2015) bahwa seseorang dengan gaya berpikir SK lebih suka mengetahui segala sesuatu dengan indera penglihatan melalui penyelidikan yang dilakukan. Oleh sebab itu, siswa dengan gaya berpikir SK selalu mengidentifikasi informasi terlebih dahulu sebelum merumuskan dan menjawab masalah. Hal itu juga sesuai dengan Zakir (2015) bahwa siswa dengan gaya berpikir SK selalu mengumpulkan fakta yang diketahui secara lengkap dan urut berdasarkan identifikasi masalah yang dilakukan.

Kemampuan memberikan dasar suatu keputusan, siswa dengan gaya berpikir SK mampu menentukan kredibilitas sumber informasi dalam membuat sebuah keputusan dengan baik. Dalam hal ini, siswa dengan gaya berpikir SK mampu menggunakan rumus dan langkah-langkah penyelesaian soal secara urut dan lengkap dalam menyelesaikan masalah sesuai apa yang direncanakan. Jadi, terdapat kecenderungan siswa dengan gaya berpikir SK dalam menyelesaikan soal selalu menyebutkan dan menuliskan langkah- langkah penyelesaian masalah secara lengkap dan urut. Hal ini sesuai dengan DePorter dan Hernacki (2015) bahwa siswa dengan gaya berpikir SK selalu mengatur tugas-tugas menjadi proses tahap demi tahap dan berusaha keras untuk mendapatkan kesempurnaan pada setiap tahap, sehingga cara yang dilakukan dengan menuliskan langkah-langkah penyelesaian secara urut dan lengkap untuk memperoleh hasil yang maksimal.

Kemampuan menyimpulkan, siswa dengan gaya berpikir SK mampu membuat kesimpulan dari kedua premis yang disajikan berdasarkan logika yang dipahaminya walaupun sedikit kurang lengkap. Sedangkan pada indikator menarik kesimpulan dan penilaian siswa dengan gaya berpikir SK mampu menarik kesimpulan berdasarkan penyelidikan yang dilakukan dengan mempertimbangkan kesesuaian sumber untuk menentukan alternatif penyelesaian sebagai bukti untuk memperkuat penilaiannya. Jadi, pada kemampuan ini terdapat kecenderungan siswa SK dalam menyimpulkan dengan menuliskan fakta/ informasi yang diketahui pada soal sebelum bertindak serta menyelesaikan permasalahan sesuai dengan yang direncanakan untuk menetapkan kesimpulan yang akurat.

Kemampuan klarifikasi lebih lanjut, siswa dengan gaya berpikir SK mampu membuat contoh dan bukan contoh berdasarkan definisi yang disajikan pada soal serta mampu mengungkapkan posisinya pada sebuah masalah dengan memberikan penjelasan lanjut terkait jawaban yang diberikan dengan baik. Pada kemampuan ini siswa dengan gaya berpikir SK juga mampu menggunakan asumsinya untuk mengidentifikasi unsur-unsur dan pengambilan sebuah keputusan.

Kemampuan dugaan dan keterpaduan seperti pada indikator menduga dan memadukan, siswa dengan gaya berpikir SK memiliki kecenderungan mampu menggunakan pengalamannya untuk menduga dan menentukan alternatif penyelesaian soal dengan tepat. Namun, kemampuan ini belum sepenuhnya dikuasai. Hal ini dikarenakan bahwa siswa dengan gaya berpikir SK memiliki kecenderungan mengikuti informasi yang diberikan pada soal tanpa menganalisisnya lebih lanjut dan hanya fokus pada satu cara penyelesai- 
an masalah, sehingga mereka tidak mampu memberikan cara lain dalam menyelesaikan masalah untuk memperoleh hasil yang sama.

\section{Kemampuan Berpikir Kritis Siswa Sekuensial Abstrak (SA)}

Berdasarkan analisis disimpulkan bahwa siswa dengan gaya berpikir SA hanya mampu memenuhi satu kemampuan berpikir kritis menurut Ennis (2011) yaitu kemampuan klarifikasi lebih lanjut. Siswa dengan gaya berpikir sekuensial acak belum mampu memenuhi kemampuan klarifikasi dasar, kemampuan memberikan dasar suatu keputusan, kemampuan menyimpulkan, dan kemampuan dugaan dan keterpaduan dengan baik.

Kemampuan klarifikasi dasar, siswa dengan gaya berpikir SA mampu mengidentifikasi soal dengan menuliskan yang diketahui pada soal secara lengkap dan urut. Hal ini sesuai dengan pendapat Zakir (2015) bahwa siswa dengan gaya berpikir SA cenderung menuliskan fakta yang diketahui secara lengkap dan terurut dengan cara identifikasi masalah yang dilakukan. Namun siswa dengan gaya berpikir SA tidak dapat memanfaatkan hasil identifikasi yang dilakukan untuk menyelesaikan permasalahan yang diberikan seperti indikator menganalisis argumen dan memberikan penjelasan terhadap masalah yang ada pada soal. Jadi, pada kemampuan klarifikasi dasar siswa dengan gaya berpikir SA hanya dapat menyebutkan informasi berdasarkan analisis informasi yang diperoleh pada soal. Hal ini sesuai dengan DePorter dan Hernacki (2015) bahwa siswa dengan gaya berpikir SA lebih suka berpikir dalam menganalisis informasi terhadap peristiwa-peristiwa yang teratur.

Kemampuan memberikan dasar suatu keputusan siswa dengan gaya berpikir SA hanya mampu menentukan kredibilitas sumber yang sesuai untuk menyelesaikan permasalahan pada soal. Siswa dengan gaya berpikir SA belum mampu menyelesaikan soal sesuai dengan prosedur yang direncanakan. Hal ini disebabkan karena siswa dengan gaya berpikir SA kurang teliti terhadap apa yang ditanyakan pada soal. Selain itu, siswa dengan gaya berpikir SA juga tidak mampu melaporkan hasil observasi yang dilakukan. Hal ini dikarenakan bahwa siswa dengan gaya berpikir SA tidak mampu untuk merencanakan prosedur yang tepat dalam melaporkan hasil observasi. Hal ini sesuai dengan Zakir (2015) bahwa siswa dengan gaya berpikir SA cenderung tidak mampu menyelesaikan permasalahan sesuai dengan prosedur yang direncanakan.

Kemampuan menyimpulkan seperti pada indikator membuat deduksi dan menilai deduksi, siswa dengan gaya berpikir SA belum mampu membuat kesimpulan berdasarkan tafsiran logika yang dipahaminya dengan benar. Sedangkan, pada indikator membuat kesimpulan dan penilaian siswa dengan gaya berpikir SA mampu memberikan kesimpulan berdasarkan hasil pekerjaan tertulisnya terhadap masalah yang yang ada pada soal. Namun, hasil tertulis perhitungan alternatif penyelesaian masalah yang di berikan kurang tepat. Hal ini dikarenakan bahwa siswa dengan gaya berpikir SA kurang teliti dalam mengidentifikasi pernyataan yang ada pada soal serta menggunakan prosedur yang tepat untuk menyelesaikan soal sesuai fakta yang diketahui.

Kemampuan membuat klarifikasi lebih lanjut seperti pada indikator mendefinisikan dan menilai definisi siswa dengan gaya berpikir SA mampu membuat contoh dan bukan contoh berdasarkan identifikasi yang dilakukan dengan memberikan penjelasan menggunakan kata-katanya sendiri tetapi maksudnya sama terhadap jawaban yang ditetapkan dengan baik. Hal ini sesuai dengan Zakir (2015) bahwa siswa dengan gaya berpikir SA akan menganalisis setiap keadaan dengan merangkai kata-katanya sendiri tetapi maksudnya sama dengan permasalahan yang diberikan untuk menentukan sebuah keputusan. Sedangkan untuk soal $6 \mathrm{c}$ siswa dengan gaya berpikir SA mampu bertindak dengan memberi penjelasan lanjut berdasarkan pertimbangan beberapa asumsi. Hal ini dikarenakan bahwa siswa dengan gaya berpikir SA mampu membuat asumsi untuk menilai pertanyaan yang ada pada soal dengan baik. Pada indikator mengidentifikasi asumsi, siswa dengan gaya berpikir SA mampu mengidentifikasi unsurunsur yang disajikan pada soal sesuai dengan asumsinya dengan baik berdasarkan analisis informasi yang dilakukan.

Kemampuan melakukan dugaan dan 
keterpaduan seperti pada indikator menduga dan memadukan siswa dengan gaya berpikir SA belum mampu memberikan alasan dan asumsi lain dengan memadukan kecenderungan dan kemampuan lain dalam menerima informasi yang diyakini dan menyelesaikan masalah seperti melakukan observasi dan mempertimbangkan penggunaan sumber yang tepat untuk menentukan alternatif penyelesaian soal yang tepat.

\section{Kemampuan Berpikir Kritis Siswa dengan Tipe Gaya Berpikir Acak Ab- strak (AA)}

Pada penelitian ini kemampuan berpikir kritis siswa dengan gaya berpikir acak abstrak hanya mampu memenuhi satu kemampuan berpikir kritis menurut Ennis (2011) yaitu pada kemampuan klarifikasi dasar sedangkan untuk kemampuan memberikan dasar suatu keputusan, kemampuan menyimpulkan, kemampuan klarifikasi lebih lanjut dan kemampuan melakukan dugaan dan keterpaduan belum dikuasai dengan baik.

Kemampuan klarifikasi dasar seperti pada indikator memfokuskan pertanyaan siswa dengan gaya berpikir AA mampu memfokuskan masalah dengan mengidentifikasi masalah dan menuliskan fakta atau informasi pada soal dengan baik sebagai pertimbangan untuk menentukan jawaban yang tepat. Hal ini sesuai dengan Setyawan (2017) bahwa siswa dengan gaya berpikir AA selalu mengidentifikasi masalah untuk menemukan solusi, sedangkan untuk indikator menganalisis argumen siswa dengan gaya berpikir AA mampu memberikan alasan terkait jawaban yang ditulisnya. Sementara itu, pada indikator menjawab pertanyaan yang membutuhkan penjelasan siswa dengan gaya berpikir AA mampu menganalisis kesimpulan sesuai fakta dengan baik.

Kemampuan memberikan dasar suatu keputusan seperti pada indikator menilai kredibilitas sumber, siswa dengan gaya berpikir AA belum mampu menentukan rumus yang sesuai untuk menyelesaikan masalah pada soal serta penggunaan prosedur yang tepat untuk menentukan alternatif penyelesaian soal. Kesalahan yang dilakukan siswa dengan gaya berpikir AA adalah tidak teliti dalam mengidentifikasi pernyataan yang ada pada soal. Sedangkan indikator melakukan observasi dan menilai hasil observasi siswa dengan gaya berpikir AA belum mampu melibatkan sedikit dugaannya untuk menentukan rumus yang tepat untuk menyelesaikan masalah berdasarkan observasi yang dilakukan.

Kemampuan menyimpulkan seperti pada indikator membuat deduksi dan menilai deduksi siswa dengan gaya berpikir AA kurang mampu memberikan kesimpulan terkait kedua premis yang disajikan pada soal dengan benar. Hal ini dikarenakan bahwa siswa dengan gaya berpikir ini terlalu lama dalam memikirkan jawaban yang sesuai. Hal ini sesuai dengan DePorter dan Hernacki (2015) bahwa siswa dengan gaya berpikir AA membutuhkan waktu lama dan tidak suka dibatasi untuk berpikir sesuai dengan kondisi dirinya. Sedangkan pada indikator menarik kesimpulan dan penilaian, siswa dengan gaya berpikir AA belum mampu memberikan kesimpulan berdasarkan asumsinya dan fakta serta pertimbangan alternatif penyelesaian masalah yang disajikan pada soal dengan baik. Hal ini dikarenakan siswa dengan gaya berpikir AA memiliki kecenderungan menarik kesimpulan berdasarkan hasil pekerjaan tertulisnya tanpa mencoba menyelesaikan kembali sesuai dengan pemahamannya.

Kemampuan klarifikasi lebih lanjut seperti pada indikator mendefinisikan dan menilai definisi siswa dengan gaya berpikir AA tidak mampu membuat contoh dan bukan contoh berdasarkan definisi yang disajikan pada soal serta mengungkapkan posisinya pada suatu permasalahan dengan bertindak memberikan penjelasan lanjut terkait pertanyaan yang ada pada soal dengan baik. Hal ini dikarenakan bahwa kedua subjek tidak memahami konsep dari barisan geometri dan keterbatasan waktu yang diberikan. Pada indikator mengidentifikasi asumsi, siswa dengan gaya berpikir AA tidak mampu membuat asumsi yang dibutuhkan dengan mengidentifikasi unsur-unsur yang ada pada soal serta menjawab pertanyaan yang ada pada soal berdasarkan asumsi yang dibutuhkan.

Kemampuan dugaan dan keterpaduan seperti pada indikator menduga dan mema- 
dukan, siswa dengan gaya berpikir AA tidak mampu memberikan alasan dan asumsi lain terkait informasi dan masalah yang disajikan pada soal dengan memadukan kemampuan lain untuk membuat sebuah keputusan. Hal ini dikarenakan bahwa siswa AA tidak mampu memanfaatkan pengalamannya untuk menyelesaikan permasalahan yang diberikan. Hal ini sesuai dengan Zakir (2015) bahwa siswa dengan gaya berpikir AA tidak dapat memanfaatkan pengalamannya untuk menyelesaikan permasalahan yang diberikan, dalam hal ini siswa dengan gaya berpikir AA tidak mampu menggunakan hasil identifikasi yang telah dilakukan untuk memberikan penilaian dan alasan dalam menyelesaikan masalah pada soal.

\section{Kemampuan Berpikir Kritis Siswa dengan Tipe Gaya Berpikir Acak Konkret (AK)}

Berdasarkan analisis, hasil penelitian ini menunjukkan bahwa kemampuan berpikir kritis siswa dengan gaya berpikir acak konkret mampu memenuhi ketiga kemampuan berpikir kritis Ennis (2011) meliputi kemampuan klarifikasi dasar, kemampuan menyimpulkan dan kemampuan memberikan dasar suatu keputusan dengan baik. Sementara, untuk kemampuan membuat klarifikasi lebih lanjut dan dugaan serta keterpaduan, siswa dengan gaya berpikir acak konkret kurang mampu menguasai dengan baik.

Kemampuan klarifikasi dasar siswa dengan gaya berpikir AK mampu memahami masalah yang ada pada soal dengan baik serta dapat memberikan respon secara lisan dan jelas dalam menjawab pertanyaan dan menganalisis argumen yang dituliskan dengan mengidentifikasi informasi sesuai fakta yang ada pada soal dengan baik. Hal ini sesuai dengan Setyawan (2017) bahwa siswa dengan gaya berpikir AK dalam mengidentifikasi masalah akan cenderung pada proses asimilasi dimana siswa mampu memahami masalah dengan baik dan dapat memberikan respon secara lisan dengan jelas.

Pada kemampuan memberikan dasar suatu keputusan seperti pada indikator mempertimbangkan kredibilitas sumber informasi, siswa dengan gaya berpikir AK mampu menentukan rumus yang tepat untuk menyelesaikan masalah namun sedikit kekurangan pada penggunaan prosedur yang tepat untuk menyelesaikan masalah. Hal ini dikarenakan ada kecenderungan mengikuti informasi yang diberikan tanpa menganalisisnya terlebih dahulu. Sedangkan pada indikator mengobservasi dan mempertimbangkan hasil observasi siswa dengan gaya berpikir AK mampu melaporkan hasil observasi dengan menuliskan sumber informasi dan mencatat hasil observasi yang dilakukan dengan baik. Hal ini terlihat pada jawaban masing-masing subjek pada hasil wawancara dimana mereka menebak untuk mengetahui informasi yang hilang dengan membuat urutan jumlah persegi pada gambar yang disediakan sebagai dasar untuk menemukan jawaban dan melaporkan hasil observasi. Hal ini sesuai dengan DePorter dan Hernacki (2015) bahwa salah satu karakteristik siswa dengan gaya berpikir acak konkret yaitu melakukan pendekatan benar-salah (trial and error).

Kemampuan menyimpulkan seperti pada indikator membuat deduksi dan menilai hasil deduksi, siswa dengan gaya berpikir AK mampu membuat kesimpulan dari kedua premis yang disajikan berdasarkan logika yang dipahaminya dengan benar. Siswa dengan gaya berpikir AK mampu menetapkan kesimpulkan sesuai dengan cara mereka sendiri namun memiliki pengertian yang sama. Hal ini sesuai dengan DePorter (2015) bahwa siswa dengan gaya berpikir AK akan mengerjakan segala sesuatu dengan cara mereka sendiri. Pada indikator membuat kesimpulan dan penilaian, kedua siswa dengan gaya brpikir AK mampu memberikan kesimpulan berdasarkan asumsinya dengan mempertimbangkan dan menentukan alternatif penyelesaian soal. Namun pada siswa AK bukti alternatif penyelesaian yang dituliskan kurang tepat. Hal ini dikarenakan siswa AK kurang teliti dalam mengidentifikasi pernyataan yang ada pada soal.

Kemampuan klarifikasi lebih lanjut seperti pada indikator mendefinisikan dan menilai definisi, siswa dengan gaya berpikir AK mampu membuat contoh dan bukan contoh berdasarkan definisi yang disajikan pada soal 
namun kurang mampu bertindak dengan memberikan penjelasan lanjut karena alasan yang dituliskan kurang benar. Hal ini disebabkan bahwa siswa AK dalam melakukan pendekatan trial-and error untuk mengambil sebuah keputusan tanpa menganalisis informasi secara terstruktur sebelum mengambil sebuah keputusan dengan baik. Pada indikator mengidentifikasi asumsi siswa dengan gaya berpikir AK mampu membuat asumsi yang dibutuhkan dengan mengidentifikasi unsur-unsur yang disajikan pada soal namun asumsi yang diberikan kurang tepat.

Kemampuan membuat dugaan dan keterpaduan seperti pada indikator menduga dan memadukan, siswa dengan gaya berpikir AK belum mampu memberikan alasan dan asumsi lain dalam menerima informasi yang diyakini dan kurang mampu memadukan kecenderungan dan kemampuan lain dalam membuat sebuah keputusan. Hal ini disebabkan bahwa siswa dengan gaya berpikir AK dalam menguji kebenaran hanya mencocokkan informasi yang ada pada soal tanpa menganalisis lebih lanjut.

\section{SIMPULAN}

Hasil penentuan tes gaya berpikir siswa dari 34 siswa, lima siswa dengan gaya berpikir sekuensial konkret, delapan siswa dengan gaya berpikir sekuensial abstrak, lima siswa dengan gaya berpikir acak konkret, dan 16 siswa dengan gaya berpikir acak abstrak. Kemampuan berpikir kritis siswa dari kelompok gaya berpikir konkret lebih baik daripada siswa dari kelompok abstrak untuk sekuensial maupun acak. Siswa dengan jenis gaya berpikir sekuensial abstrak dan acak abstrak memiliki kemampuan berpikir kritis rendah dibandingkan dengan gaya berpikir lainnya. Siswa dengan gaya berpikir sekuensial konkret mampu menguasai kemampuan 1, 2, 3, dan 4. Siswa dengan gaya berpikir sekuensial abstrak hanya mampu menguasai kemampuan 4 . Siswa dengan gaya berpikir acak abstrak mampu menguasai kemampuan 1 . Siswa dengan gaya berpikir acak konkret mampu menguasai kemampuan 1, 2, dan 3.

Adapun saran dari peneliti sebagai masukan bagi beberapa pihak, diantaranya: guru sebaiknya menggunakan cara mengajar se- suai dengan jenis gaya berpikir siswanya dan menggunakan strategi maupun metode pembelajaran yang sesuai dengan kemampuan berpikir kritis siswa yang belum tercapai sehingga dapat mengembangkan kemampuan berpikir kritis siswanya. Guru hendaknya tidak menyendirikan siswa dengan tipe gaya berpikir acak abstrak maupun sekuensial abstrak dalam suatu kelompok diskusi. Alangkah lebih baik guru menggabungkan masing-masing gaya berpikir dalam satu kelompok diskusi. Harapannya ada yang dapat membantu saat menyelesaikan masalah dalam suatu kelompok. Sementara itu, bagi peneliti lain, perlu diadakan penelitian lanjutan yang membahas mengenai komparasi kemampuan berpikir kritis siswa dengan perbandingan antara masing-masing gaya berpikir.

\section{DAFTAR PUSTAKA}

DePorter, B \& Hernacki, M. (2015). Quantum Learning: Membiasakan Belajar Nyaman dan Menyenangkan. Bandung: Kaifa.

Duron, R., Limbach, B., \& Waugh, W. (2006). Critical thinking framework for any discipline. International Journal of Teaching and Learning in Higher Education, 17(2), 160-166.

Ennis, R. H. (2011, July). The nature of critical thinking: An outline of critical thinking dispositions and abilities. In Sixth International Conference on Thinking, Cambridge, MA (pp. 1-8).

Hendriana, H., Rohaeti, E.E., \& Sumarmo, U. (2017). Hard skills dan soft skills matematik siswa. Bandung: Refika Aditama.

Iswadi, H. (2016). Sekelumit dari hasil PISA 2015 yang baru dirilis. Surabaya: Universitas Surabaya.

Marwan, M. Ikhsan \& Marwan. (2016). Meningkatkan Kemampuan Berpikir Kritis Matematis Siswa SMK melalui Model Pembelajaran Berbasis Masalah. Jurnal Didaktik Matematika, 3(2), 9-18.

Mulyono. (2012). Strategi Pembelajaran Menuju Efektivitas Pembelajaran di Abad lobal. Malang: UINMaliki Press.

Paul, R., \& Elder, L. (2006). The miniature guide to critical thinking: Concepts \& tools. Dillon Beach, CA: Foundation for Critical Thinking.

Peraturan Menteri Pendidikan dan Kebudayaan nomor 21 tentang Standar Isi Pendidikan dasar dan Menengah.

Peraturan Menteri Pendidikan dan Kebudayaan nomor 58 tentang Pedoman Mata Pelajaran Matematika.

Rahmawati, I., Hidayat, A., \& Rahayu, S. (2016). Analisis keterampilan berpikir kritis siswa SMP pada materi gaya dan penerapannya. Pros. Semnas Pend. IPA Pascasarjana UM, 1, 1112-1118.

Setyawan, D. (2017). Exploration of Students Knowledge Construction Process on Geometry Througt Ran- 
dom Thinking Style and Spatial Ability of Mental Eotation Level. Jurnal Ecosystem, 17(1), 643-652. Somakim. (2011). Peningkatan Kemampuan Berpikir Kritis Matematis Siswa Sekolah Menengah Pertama dengan Penggunaan Pendidikan Matema- tika Realisitik. Jurnal Forum MIPA, 14(1), 42-48. Zakir, M. (2015). Description of Logical Reasoning In Solving Mathematics Problemss Based On Students' Thinking Style Of Students at SMPN 2 Pinrang. Jurnal Daya Matematis, 3(2), 152-165. 